connexion, it is worth while directing attention to an article in the July issue of the Nautical Magazine, in which Sir John Graham Kerr discusses camouflage in its application to ships at sea. The article includes a reprint of the original letter drafted by Prof. Graham Kerr, as he then was, and circulated by the Admiralty to the Navy on November 10, 1914, on the use of paint camouflage for diminishing the visibility of ships at a distance. Effective camouflage, whether on land or sea, depends on two fundamental principles: compensative or counter-shading, and parti-colouring or disruptive pattern. The effect of imitative colouring, the basis of the artist's technique, is entirely overborne by the effects of light and shadow.

Sir John points out that complete invisibility by the use of paint camouflage is out of the question. In bright light and a clear atmosphere, it is impossible to hide a large object such as a ship at sea, but in conditions of poor visibility, properly devised camouflage can make it extremely difficult to 'pick up' a ship and can disguise effectively its character, size and course. The trial or adoption of Sir John's suggestions were left to individual flag officers, and this may have accounted for the very indifferent results obtained. In 1917 a modification of these proposals was adopted, under the guidance of Mr. Nor-

man Wilkinson (now president of the Royal Institute of Painters in Water Colours), to which the American biological term 'dazzle' was given, and was widely used for the mercantile marine, American destroyers and certain British war-vessels. As we have already pointed out, present-day methods of paint camouflage are largely ineffective, due in part to lack of co-ordination of the various departments concerned and to lack of scientific direction.

\section{Memorial to Prof, J. H. Ashworth}

The bronze memorial plaque to the late Prof. J. H. Ashworth, a reproduction of which appears on this page, set in Yorkshire monumental stone, was unveiled at Salem Congregational Church, Burnley, by Mrs. Ashworth on June 25. Prof. Ashworth was a Burnley man, and although he spent the last twenty-five years of his life at Edinburgh, he never allowed the link with his birth-place to be broken. As professor of natural history in the University of Edinburgh, he achieved an international reputation, and by his death at the early age of sixty-one on February 4, 1936, the world lost a distinguished zoologist; NATURE lost a valued contributor whose services had extended over many years.

After the unveiling ceremony, at which the Mayor of Burnley presided, addresses were given by, among others, Prof. H. Graham Cannon, professor of zoology in the University of Manchester, and the Rev. T

Ormerod, chairman of the Memorial Committee; Dr. W. Howarth, director of education at Burnley and honorary secretary of the Memorial Committee, read tributes received from Sir Thomas Holland, principal of the University of Edinburgh, Sir George Adam Smith, formerly principal of the University of Aberdeen, Sir Richard Gregory, president of the British Association and former editor of NATURE, and others. Prof. Ashworth was a great friend, a great zoologist, and a great teacher and administrator. $\mathrm{He}$ was the first in Great Britain to introduce a course of medical zoology, and when the time came to re-organize and build a new department of natural history in the University of Edinburgh, his powers were shown to the full. The building there which now bears his name is a lasting and worthy memorial in the community of his adoption.

\section{Prof. W. P. Alexander}

Prof. William P. Alexander has been awarded the Cornelius Amory Pugsley Medal of the Buffalo Museum of Science, for his work as a conservationist and naturalist. The medal, established by Chester D. Pugsley of Peekskill, N.Y., in honour of his father, bears the inscription: "Awarded to William Prindle Alexander for his distinguished work as a pioneer of outdoor education in state parks". Prof. Alexander, who is Hayes professor of natural history at the Buffalo Museum of Science, is widely known as a lecturer, writer, and teacher of natural history subjects. He was the originator of the Nature trail idea, his first trail having been planned in the Allegany State Park in 1921 ; it is now an established institution in many State and Federal parks. Prof. Alexander 
is a conservationist, not in the sense that he seeks to protect wild life out of season, so that the mute and helpless creatures of wood and field can be indiscriminately maimed and slaughtered 'in season', but as a protector and preserver of all wild life in every season. In addition to being the author of numerous articles on natural history, he has had published several novels.

\section{Dr. Tweedie John Todd}

Dr. TweEdiE JoHn TodD, physician and naturalist, was born at Berwick in 1789, the son of the borough treasurer. He studied medicine at Edinburgh and for several years served as a surgeon in the Navy, chiefly in the East Indies and at the Cape of Good Hope, where he made some experiments on the electric ray (Torpedo), which were afterwards published in the Philosophical Transactions. He retired from the Navy in 1816, and after spending some years in Italy settled in Brighton, where he soon acquired an extensive practice. $\mathrm{He}$ was the author of several papers on natural history which were published in the Philosophical Transactions and the Journal of Science and Arts, such as "The Regeneration of Parts in the Aquatic Salamander" and "The Luminous Power of Some of the Lampyrides". His contribution to medical literature consisted of "The Book of Analysis. A New Method of Experience", in which he endeavoured to apply Baconian induction to medicine and the other natural sciences. For many years he was engaged in a series of microscopical researches on living animals illustrative of different parts of physiological and pathological science and especially of the processes concerned in the healing and regeneration of wounded and lost parts. He left a large collection of microscope slides at the time of his death, which took place on August 4, 1840.

\section{University Students and Compulsory Service}

Dr. RAYMond PrIestley, vice-chancellor of the University of Birmingham, in the course of a circular letter addressed to head masters of a number of schools in the Midlands, has pointed out that the age at which undergraduates will be called up for military service has been fixed by the Government at twenty years. This will enable many men to complete their university training before entering the Services. With the object of enhancing the value of such men to the national effort, it has been decided by the University of Birmingham that all future entrants will be required to choose one of the following options as part of their university course: (I) compulsory physical education for one year; or (2) two years service in the University contingent of the O.T.C. Those who choose the latter will be accepted for the O.T.C. only if they are approved by an interviewing board set up by the Military Education Committee, the main criteria being personality and power of leadership (latent or developed). Training in the O.T.C. will be carried out with the view of developing powers of leadership rather than training technical experts, and should prove of great interest and value to all who join, in whatever walk of life they may afterwards find themselves. The advantages of this general military training apply equally to those taking medical and dental courses, since the military background essential to an R.A.M.C. officer can be adequately acquired in this way. Those who obtain War Certificates A and B will have definite advantages when they are called up for military service; the scheme should go far towards ensuring that the best use is made of all those suitable as officers.

\section{Fire Risk from the Smashing of Filament Lamps}

ExpERIMENT shows that it is difficult to cause ignition of combustible material by means of smashing a filament lamp embedded in it. But the lampholder of a large lamp may rise to a fairly high temperature, high enough to explode certain compounds used for military purposes. It is well known that sudden breakage of a glass bulb may occur during heavy gunfire in a battleship or cruiser. It could also happen in a submarine when depth charges are exploding near it. This explains the interest now being taken in the United States Navy in fluorescent lighting for magazines and in other parts of a warship where explosives are handled. It is very difficult to set fire even to cotton-wool by smashing a lighted fluorescent lamp reposing on it.

A useful feature of the mercury fluorescent lamp is that it can easily be so graded as to emit the tone of blue light that is preferred for darkening a ship when in action at night. At present this reduced lighting effect is obtained by shading tungsten filament lamps and using a blue glass bulb, or one which has been sprayed in that colour. The Electrical Times of July 4 states that the U.S. Navy is having a series of experiments made with fluorescent lighting, and if it is found that this type obviates the danger due to filament lamps overheating in tropical atmospheres or when they are smashed by heavy gunfire, the mercury discharge type with fluorescent effect may find an extensive use in warships and elsewhere. It is also being recommended for mines, gasworks, petrol and benzine factories, hydrogen plant and all other places where the air is charged with explosive vapours or dust.

\section{Daylight Observation of Venus and Jupiter}

Dr. A. L. PEck, of Christ's College, Cambridge, writes: "In view of the astronomical notes in NaTuRE of July 27 , p. 128 , it may be of interest to record that two planets were picked out here with the naked eye on July 28, at 9.40 a.m. B.S.T.Venus (daylight observation of which is, of course, nothing unusual) and Jupiter. Observation of the latter was made possible by its proximity to the moon, with which it had been in conjunction a few hours before."

\section{British Museum (Natural History): Acquisitions}

The Zoological Department has received as a donation from Admiral Sir Sidney Bailey, a series of mounted heads of North American ungulates, including a very fine moose and some exceptionally good wapiti and caribou. The collection also contains a head of a Rocky Mountain goat. Another interesting 